\title{
Transport of mannose by an inducible phosphoenolpyruvate: fructose phosphotransferase system in Streptococcus salivarius
}

\author{
Gilles Pelletier, Michel Frenette and Christian Vadeboncoeur
}

Author for correspondence: Christian Vadeboncoeur. Tel : +1 418656 2319. Fax: +1 4186562861.

Group de Recherche en Ecologie Buccale (GREB), Département de biochimie (Sciences) and Faculté de médecine dentaire, Université Laval, Québec, (Québec), G1K 7P4, Canada

\begin{abstract}
Streptococcus salivarius transports mannose by a phosphoenolpyruvate:sugar phosphotransferase system (PTS) which consists of a membrane Enzyme II and two forms of Enzyme III (IIIMan) with molecular masses of 38.9 kDa (IIIMan) and $35 \cdot 2 \mathrm{kDa}$ (IIIMan) respectively. Using a pseudorevertant (strain 57P) isolated from a IIIMan-deficient spontaneous mutant unable to grow on mannose, we demonstrated that $S$. salivarius could also transport mannose by an inducible fructose PTS. This PTS phosphorylated fructose at the $\mathrm{C}-1$ position with a high affinity $(10 \mu \mathrm{M})$ and mannose at the C-6 position with a low affinity (200 $\mu \mathrm{M})$. Derepression of this system in some IIIMan-deficient mutants would explain their ability to grow on mannose.
\end{abstract}

Keywords: Streptococcus salivarius, phosphoenolpyruvate:sugar phosphotransferase system, transport, fructose, mannose

\section{INTRODUCTION}

Transport of sugars in streptococci is mediated principally by the phosphoenolpyruvate:sugar phosphotransferase system (PTS) which concomitantly catalyses the phosphorylation and the translocation of mono- and disaccharides across the membrane via a chain of enzymic reactions that transfer a phosphate group from PEP to the incoming sugar (Thompson, 1987; Meadow et al., 1990; Postma et al., 1993). In Streptococcus salivarius, mannose is transported by a constitutive PTS consisting of a membrane-bound EII Man and two forms of III ${ }^{\text {Man }}$, with molecular masses of $38.9 \mathrm{kDa}\left(\mathrm{III}_{\mathrm{H}}^{\mathrm{Man}}\right)$ and $35.2 \mathrm{kDa}$ $\left(\right.$ III $\left._{\mathrm{L}}^{\mathrm{Mall}}\right)$, which are found associated with the membrane as well as free in the cytoplasm (Vadeboncoeur \& Gauthier, 1987; Bourassa et al., 1990). The system has a broad specificity, recognizing mannose, glucose, fructose and 2DG (Vadeboncoeur, 1984) and is involved in several types of regulatory functions including control of gene expression and diauxic growth on sugars (Bourassa \& Vadeboncoeur, 1992; Brochu et al., 1993; Gauthier et al., 1990; Lapointe et al., 1993).

We previously reported the isolation and characterization of several $\mathrm{III}_{\mathrm{L}}^{\mathrm{Man}}$-deficient mutants (Bourassa \&

Abbreviations: 2DG, 2-deoxyglucose; El, Enzyme I; Ell, Enzyme II; PTS, phosphoenolpyruvate:sugar phosphotransferase system; PEP, phosphoenolpyruvate; III Man and IIIMan, low and high molecular mass forms of III ${ }_{\mathrm{L}}^{\text {Man }}$.
Vadeboncoeur, 1992; Brochu et al., 1993; Gauthier et al., 1990; Lapointe et al., 1993). On the basis of their ability to grow on mannose, these mutants can be divided into two groups: some strains are unable to grow on $0.2 \%$ mannose whereas others can grow on $0.2 \%$ mannose, albeit very slowly. The growth of the mutants of the second group is, however, improved by increasing the concentration of mannose in the culture medium, suggesting that mannose is transported in these mutants by a low-affinity transport system. We also found that an inducible $\mathrm{EII}^{\mathrm{Fru}}$ is derepressed in $\mathrm{III}_{\mathrm{L}}^{\mathrm{Man}}$-deficient mutants able to grow on mannose but normally controlled in the other mutants. This inducible EII ${ }^{\text {Fru }}$ has been identified and is a membrane protein of molecular mass $57.5 \mathrm{kDa}$ (Bourassa \& Vadeboncoeur, 1992). We present in this work results demonstrating that this inducible EII ${ }^{\text {Fru }}$ is also able to transport mannose.

\section{METHODS}

Bacterial strains and growth conditions. The parental strain used in this study was Streptococcus salivarius ATCC 25975, provided by Dr I. R. Hamilton (University of Manitoba, Canada). The isolation and partial characterization of the spontaneous III $_{\mathrm{L}}^{\text {Man }}$-negative mutant $\mathrm{A} 37$ as well as the culture conditions were reported previously (Gauthier et al., 1990).

Isolation of strain 57P. Strain $57 \mathrm{P}$ was isolated by plating approximately $10^{8}$ cells of the mannose PTS-deficient mutant A37 grown on glucose on a medium containing $0.4 \%$ mannose. PTS components. EI and HPr were purified from S. salivarius 
A TCC 25975 according to the method of Rodrigue et al. (1988). Membrane-free cellular extracts as well as membranes containing the EII ${ }^{\text {Man }} / \mathrm{III}^{\text {Man }}$ complex and the other EIIs were prepared as follows. Cells were ground with levigated alumina ( $3 \mathrm{~g}$ alumina per $\mathrm{g}$ wet cell paste) for $20 \mathrm{~min}$ in a refrigerated mortar $\left(-40^{\circ} \mathrm{C}\right)$, and $2 \mathrm{ml} 10 \mathrm{mM}$ potassium phosphate ( $\mathrm{pH} 7 \cdot 5$ ) containing $1 \mathrm{mM}$ EDTA, $14 \mathrm{mM}$ 2-mercaptoethanol, $0.1 \mathrm{mM}$ PMSF, $0.1 \mu \mathrm{M}$ Pepstatin A and $0.1 \mu \mathrm{M}$ Leupeptin was added for each gram of cells. Alumina was removed by centrifugation at $3000 \mathrm{~g}$ for $5 \mathrm{~min}$, and cell debris and intact cells were sedimented at $16000 \mathrm{~g}$ for $20 \mathrm{~min}$. The supernatant (membrane-free cellular extract) was collected and membrane fragments were sedimented at $140000 \mathrm{~g}$ overnight. The resulting pellet was resuspended in $10 \mathrm{mM}$ potassium phosphate ( $\mathrm{pH} 7.5$ ) containing $1 \mathrm{mM}$ EDTA, $14 \mathrm{mM}$ 2-mercaptoethanol, $0.1 \mathrm{mM}$ PMSF, $0.1 \mu \mathrm{M}$ Pepstatin $\mathrm{A}$ and $0.5 \mathrm{M} \mathrm{KCl}$ and then centrifuged once more at $180000 \mathrm{~g}$ for $5 \mathrm{~h}$. The membranes were then suspended in the same buffer without $\mathrm{KCl}$ and frozen at $-20^{\circ} \mathrm{C}$.

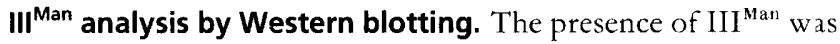
determined by SDS-PAGE and Western blotting. Cells were grown overnight in $10 \mathrm{ml}$ medium containing $0.2 \%(\mathrm{w} / \mathrm{v})$ glucose. Three millilitres of the culture were centrifuged and the pellet was resuspended in $150 \mu \mathrm{l} 10 \mathrm{mM}$ potassium phosphate (pH 7.5) containing $1 \mathrm{mM}$ EDTA, $0.3 \%$ SDS and $0.72 \mu \mathrm{M} 2-$ mercaptoethanol, and sonicated at room temperature with the pulse mode (14 pulses) at energy level 5 with a model W 350 sonicator from Heat System-Ultrasonic. After sonication, the suspension was boiled for $5 \mathrm{~min}$. The proteins in the sample were then separated by PAGE in the presence of SDS as described by Laemmli (1970) except that the stacking gel contained $4 \%(\mathrm{w} / \mathrm{v})$ acrylamide and $125 \mathrm{mM}$ Trizma base (Sigma). Proteins were then transferred electrophoretically to nitrocellulose paper $(0.45 \mu \mathrm{m}$ pore size $)$ in $25 \mathrm{mM}$ Tris $/ \mathrm{HCl}$, $192 \mathrm{mM}$ glycine, $20 \%(\mathrm{v} / \mathrm{v})$ methanol buffer ( $\mathrm{pH} 8.3$ ) according to the method of Towbin et al. (1979). Blotting was done with rabbit polyclonal antibodies directed against $\mathrm{III}_{\mathrm{H}}^{\mathrm{Man}}$ and ant rabbit alkaline phosphatase conjugate as described by Bio-Rad. Anti-III Man antibodies react with both $\operatorname{III}_{\mathrm{H}}^{\text {Man }}$ and $\mathrm{III}_{\mathrm{L}}^{\text {Man }}$ (Bourassa et al., 1990).

Uptake experiments. The uptake of $\left[{ }^{14} \mathrm{C}\right]$ sugars by cells was performed at $10^{\circ} \mathrm{C}$ (except for the uptake of mannose by strain $57 \mathrm{P}$ which was conducted at $37^{\circ} \mathrm{C}$ ) as described by Bourassa 8 : Vadeboncoeur (1992) in a medium containing $50 \mathrm{mM}$ sodium phosphate buffer $(\mathrm{pH} 7 \cdot 0)$ and $10 \mathrm{mM}$ iodoacetate.

Phosphorylation of proteins using [ $\left.{ }^{32} \mathrm{P}\right] \mathrm{PEP} .\left[{ }^{32} \mathrm{P}\right] \mathrm{PEP}$ was synthesized from $\left[\gamma^{32} \mathrm{P}\right] \mathrm{A} T \mathrm{~T}$ using purified PEP carboxykinase from Eschericbia coli K12 (kindly provided by Dr A. H. Goldie, University of Saskatchewan, Canada) as described by Mattoo \&: Waygood (1983). The procedure of Waygood et al. (1986) fo: the phosphorylation of proteins was followed with sligh: modification. Samples were incubated for $6 \mathrm{~min}$ at room temperature in $60 \mu \mathrm{l}$ medium containing $0.1 \mathrm{mM}\left[^{32} \mathrm{P}\right] \mathrm{PEI}$ (10 c.p.m. nmol ${ }^{-1}$ ), $5 \mathrm{mM} \mathrm{MgCl}_{2}, 12.5 \mathrm{mM} \mathrm{NaF}$ and $0.01 \mathrm{M}$ HEPES (pH 7.5). Fresh membrane preparations (150 $\mu \mathrm{g}$ protein), $1 \mu \mathrm{g}$ EI and $3 \mu \mathrm{g} H \operatorname{Pr}$ from S. salivarius were used. The reaction was stopped by the addition of $20 \mu \mathrm{l}$ of a solution containing $0 \cdot 188 \mathrm{M}$ Tris $/ \mathrm{HCl}(\mathrm{pH} 8 \cdot 0), 6 \%$ (w/v) SDS, $30 \%$ (v/v) glycerol, $6 \%(\mathrm{v} / \mathrm{v})$ 2-mercaptoethanol and $5 \mu \mathrm{l} 0.005 \%$ bromophenol blue. Samples were loaded on a $12.5 \%(\mathrm{w} / \mathrm{v})$ acrylamide gel over a $30 \mathrm{~min}$ period during which the samples were at room temperature. A current of $25 \mathrm{~mA}$ per gel was applied during the electrophoresis. Phosphoproteins were detected by autoradiography of dried gels performed at room temperature using Kodak $\mathrm{X}$-ray films ( $\mathrm{X}$-Omat $\mathrm{AR}$ ) with exposure times ranging from 5 to $18 \mathrm{~h}$.
Assay for Ell activity. EII activity was assayed as described by Hamilton et al. (1989) by measuring the PEP-dependent phosphorylation of ${ }^{14} \mathrm{C}$-labelled sugars by EII-containing membranes in the presence of excess purified HPr and EI.

Analytical procedures. Total protein was measured by the Lowry method with bovine serum albumin as the standard. Mannose 6-phosphate was assayed at room temperature by the enzymic method of Gracy \& Noltman (1968). The assay medium contained in $1 \mathrm{ml}: 50 \mathrm{mM}$ imidazole $/ \mathrm{HCl}(\mathrm{pH} \mathrm{7.0)}, 1.5 \mathrm{mM}$ $\mathrm{NADP}^{+}, 1.8 \mathrm{U}$ glucose-6-phosphate dehydrogenase, $4.2 \mathrm{U}$ glucose-6-phosphate isomerase, $1 \mathrm{U}$ phosphomannose isomerase and $100 \mu \mathrm{l}$ of the sample to be analysed. The amount of mannose 6-phosphate was determined after $15 \mathrm{~min}$ by measuring the optical density at $340 \mathrm{~nm}$.

\section{RESULTS}

\section{Mannose transport by Ell ${ }^{\mathrm{Fu}}$}

Mutant A37 was isolated as a spontaneous 2DG-resistant strain from $S$. salivarius ATCC 25975. This mutant lacks $\mathrm{III}_{\mathrm{L}}^{\mathrm{Man}}$ and, consequently, is unable to grow on $0.2 \%$ mannose (generation time $>600 \mathrm{~min}$ ) (Gauthier et al., 1990). Strain 57P, derived from mutant A37, has, however, recovered the ability to grow on $0.2 \%$ mannose (generation time $90 \mathrm{~min}$ ), albeit at a reduced rate when compared to the wild-type strain (generation time $40 \mathrm{~min}$ ). Strain 57P was not a revertant to the wild-type

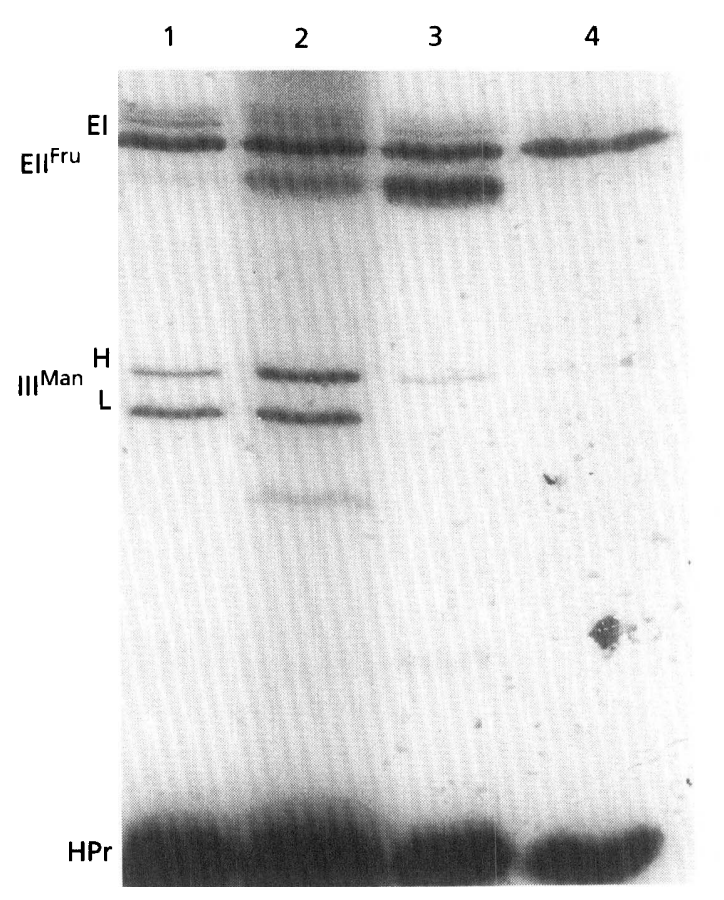

Fig. 1. $\left[{ }^{32} \mathrm{P}\right] \mathrm{PEP}$-dependent phosphorylation of membrane proteins prepared from wild-type cells of $S$. salivarius grown on glucose (lane 1) and fructose (lane 2), cells of pseudorevertant 57P grown on glucose (lane 3) and cells of mutant A37 grown on glucose (lane 4). The samples were analysed by SDS-PAGE with the resolving gel containing $12 \%$ acrylamide, followed by autoradiography. Prior to electrophoresis, samples were incubated for $6 \mathrm{~min}$ with $0.1 \mathrm{mM}$ [ $\left.{ }^{32} \mathrm{P}\right] \mathrm{PEP}$ in the presence of purified $\mathrm{HPr}(3 \mu \mathrm{g})$ and purified $\mathrm{EI}(1 \mu \mathrm{g})$ as described in Methods. 
Table 1. Ell activities for fructose and mannose in membranes of glucose- or fructose-grown cells of $S$. salivarius, mutant $\mathrm{A} 37$ and pseudorevertant 57P

The reaction mixture $(600 \mu \mathrm{l})$ contained $50 \mathrm{mM}$ sodium phosphare ( $\mathrm{pH} \mathrm{7} \cdot 0$ ), $4 \mathrm{mM} \mathrm{MgCl}_{2}$, 2 mM PEP, $5 \mathrm{mM} \mathrm{2-}$ mercaptecthanol, $10 \mathrm{mM} \mathrm{NaF}, 1 \mathrm{mM}{ }^{14} \mathrm{C}$-labelled sugars $[0 \cdot 1 \mu \mathrm{Ci}$ $\mu \mathrm{mol}^{-1}\left(37.5 \mathrm{kBq} \mu \mathrm{mol}^{-1}\right)$ ], $50 \mu \mathrm{g} \mathrm{HPr}, 1 \mu \mathrm{g} \mathrm{EI}$, and membrane fragments (200 $\mu \mathrm{g}$ protein) as a source of EII and III ${ }^{\text {Man }}$. Activities are expressed as nmol phosphorylated sugar ( $\mathrm{mg}$ membrane protein $)^{-1}(60 \mathrm{~min})^{-1}$. The values are the means of two to three determinations except for activities of fructosegrown cclls of strain 57P. The standard deviations of the means were less than $15 \%$

\begin{tabular}{|cccc|}
\hline Strain & $\begin{array}{c}\text { Growth } \\
\text { sugar }\end{array}$ & \multicolumn{2}{c|}{ EII activities for: } \\
\cline { 3 - 4 } & & Fructose & Mannose \\
\hline Wild-type & Glucose & 317 & 358 \\
& Fructose & 1575 & 423 \\
& Glucose & 287 & 35 \\
& Fructose & 2476 & 234 \\
& Glucose & 2354 & 734 \\
& Fructose & 2481 & 524 \\
\hline
\end{tabular}

phenotype as it was still devoid of $\operatorname{III}_{\mathrm{L}}^{\mathrm{Man}}$ as revealed by Western blot experiments using anti-III ${ }^{\text {Man }}$ antibodies (not shown) and by PEP-dependent phosphorylation of proteins (Fig. 1).

In order to determine whether the transport system that allowed pseudorevertant 57P to metabolize mannose was a PTS, we measured EII activities in the wild-type strain, in mutant A37 and in strain 57P after growth on glucose and fructose. Results shown in Table 1 indicate that glucuse-grown cells of strain 57P possessed, as opposed to mutant A37, mannose-PTS activity. Several lines of evidence suggested that this activity was independent of the mannose-PTS involving III ${ }^{\mathrm{Man}}$ but was related to the EII ${ }^{\text {Fru. }}$. First, addition of crude preparation of III $^{\text {Man }}$ stimulated mannose-PTS activity in the wild-type strain but not mannose-PTS activity in strain 57P (not shown), indicating that the PEP-dependent phosphorylation of mannose observed in this strain was not catalysed by the mannose-PTS. We previously reported (Gauthier et al., $1990)$ that III ${ }^{\text {Man }}$ preparations containing both forms of III ${ }^{M: n}$ do not complement the defect in several spontaneous $\mathrm{III}_{\mathrm{L}}^{\mathrm{Man}}$-deficient mutants including A37, suggesting either that soluble $\mathrm{III}_{\mathrm{L}}^{\mathrm{Man}}$ interacts poorly with EII $^{\mathrm{Man}}$ or that EII ${ }^{\mathrm{Man}}$ is not expressed in these mutants. It was therefore not surprising that crude III ${ }^{\text {Man }}$ preparations did not complement the defect in strain 57P. Second, fructose-PTS activity was derepressed in glucose-grown cells of pseudorevertant 57P (Table 1). Derepression of EII $^{\mathrm{Fru}}$ was confirmed by analysis of phosphoproteins produced by incubating membranes with $\left[{ }^{32} \mathrm{P}\right] \mathrm{PEP}$ and purified EI and HPr (Fig. 1). Results clearly showed that a phosphoprotein of molecular mass $57 \cdot 5 \mathrm{kDa}$ corresponding to EII ${ }^{\mathrm{Fru}}$ (Bourassa et al., 1992) was present in strain 57P after growth on glucose but not in mutant A37. Results shown in Fig. 1 also illustrate the lack of III $_{\mathrm{L}}^{\mathrm{Man}}$ in the pseudorevertant 57P and reveal another phosphoprotein of unknown function with a molecular mass of approximately $28 \mathrm{kDa}$. It is unlikely that this protein was a mutant form of $\mathrm{III}_{\mathrm{L}}^{\mathrm{Man}}$, as we demonstrated by Western blot experiments that it did not react with anti-III Man polyclonal antibodies (not shown). Third, mannose PTS activity increased in mutant A37 after growth on fructose (Table 1). Finally, mannose-PTS activity in strain 57P and in fructose-grown cells of mutant A37 was inhibited by fructose but not by glucose, a substrate of the mannosePTS (not shown).

\section{Kinetics and competition studies}

Fructose can be transported by $S$. salivarius by two PTS: the constitutive mannose-PTS involving the III ${ }^{\mathrm{Man}} \mathrm{com}-$ plex and the inducible fructose-PTS (Bourassa \& Vadeboncoeur, 1992). A Hofstee plot for the rate of entry of fructose in fructose-grown cells of the wild-type strain showed a biphasic curve, confirming the presence of two transport systems for fructose, a high-affinity transport system $\left(K_{\mathrm{s}}=10 \mu \mathrm{M}\right)$ and a low-affinity transport system $\left(K_{\mathrm{s}}=66 \mu \mathrm{M}\right)$ (Fig. 2a). Measurement of fructose entry into glucose-grown cells (Fig. 2b) and fructose-grown cells (not shown) of strain 57P as a function of fructose concentration revealed the presence of a single highaffinity transport system with a $K_{\mathrm{s}}$ of $9.5 \mu \mathrm{M}$, indicating that the inducible fructose-PTS, derepressed in strain 57P, was the high-affinity system. The affinity of this system for mannose was determined by measuring the entry of mannose into glucose-grown cells of strain $57 \mathrm{P}$ as a function of mannose concentration (Fig. 2c). Mannose uptake in this $\mathrm{III}_{\mathrm{L}}^{\mathrm{Man}}$-deficient strain was concentrationdependent and obeyed saturation kinetics, thus implying a carrier-mediated uptake. The apparent $K_{\mathrm{s}}$ was $196 \mu \mathrm{M}$. The uptake of fructose by glucose-grown cells of strain 57P was competitively inhibited by mannose (Fig. 3). The inhibition constant $\left(K_{\mathrm{i}}\right)$, determined by the method of Dixon (1953), was $200 \mu \mathrm{M}$, which corresponded to the apparent $K_{\mathrm{s}}$ found for mannose. These results substantiated the hypothesis that the inducible fructose-PTS of $S$. salivarius also transports mannose. This implied that mannose uptake by fructose-grown cells of the wild-type strain is catalysed by two transport systems: a highaffinity system (the constitutive mannose-PTS) and a lowaffinity system (the inducible fructose-PTS). The Hofstee plot of mannose uptake by fructose-grown cells of the wild-type strain exhibited a biphasic curve, demonstrating the presence of a high-affinity system (apparent $\left.K_{\mathrm{s}}=10.5 \mu \mathrm{M}\right)$ corresponding to the mannose-PTS and the presence of a low-affinity system (apparent $\left.K_{\mathrm{s}}=176 \mu \mathrm{M}\right)$ corresponding to the inducible fructosePTS (Fig. 2d).

\section{Nature of the reaction product}

The fate of mannose subsequent to phosphorylation by the inducible fructose-PTS was determined by allowing membranes isolated from glucose-grown cells of strain 


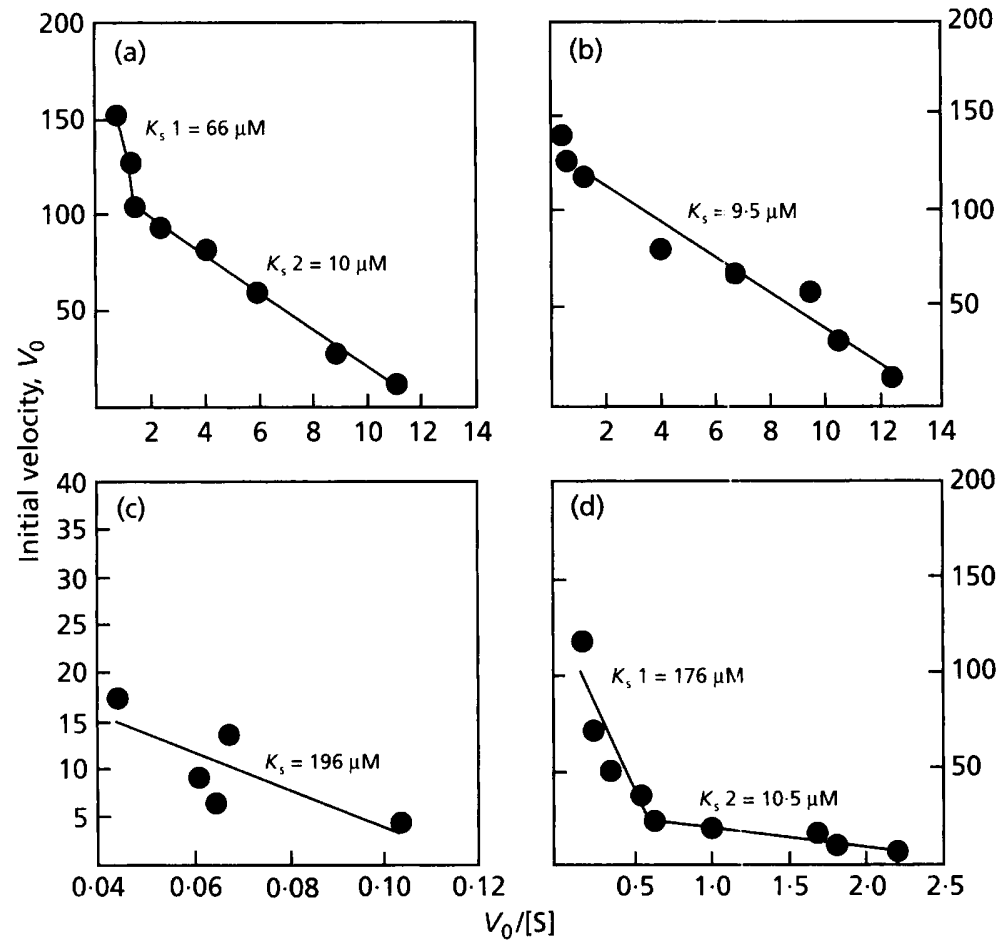

Fig. 2. (a, b) Hofstee plots of fructose uptake by: (a) wild-type cells of $S$. salivarius grown on fructose and (b) glucose-grown cells of pseudorevertant 57P. (c, d) Hofstee plots of mannose uptake by (c) glucose-grown cells of pseudorevertant 57P and (d) fructosegrown wild-type cells. Cells were harvested during the exponential phase of growth, washed, and incubated for $15 \mathrm{~s}$ in the presence of ${ }^{14} \mathrm{C}$-labelled sugar as described in Methods. The sugar concentration and the specific radioactivity ranged from $1 \mu \mathrm{M}$ to $1600 \mu \mathrm{M}$ and from 0.1 to $1 \mu \mathrm{Ci} \mu \mathrm{mol}^{-1}$ $\left(3 \cdot 7-37 \mathrm{kBq} \mu \mathrm{mol}^{-1}\right)$ respectively.

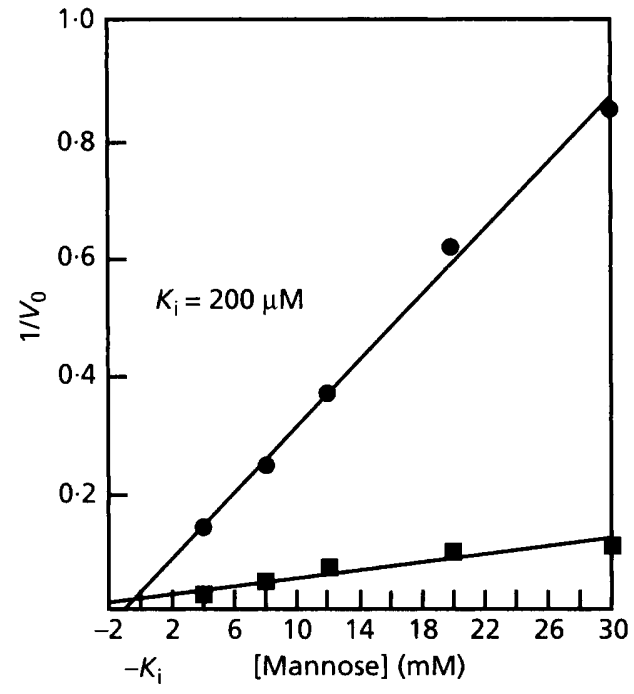

Fig. 3. Inhibition of fructose uptake by mannose in glucosegrown cells of strain 57P. The initial velocities $\left(V_{0}\right)$ are expressed as $\mathrm{nmol}$ fructose incorporated (mg protein) $)^{-1} \mathrm{~min}^{-1}$.

Fructose $1 \mu \mathrm{M} ; \mathbf{\square}$, fructose $6 \mu \mathrm{M} ; K_{\mathrm{i}}=$ inhibition constant.

57P to phosphorylate mannose, at the expense of PEP, in the presence of purified EI and HPr. We demonstrated the presence of mannose 6-phosphate by measuring its transformation to 6-phosphate gluconolactone by the enzymes mannose-6-phosphate isomerase, glucose-6phosphate isomerase and glucose-6-phosphate dehydrogenase, with the concomitant reduction of $\mathrm{NADP}^{+}$ (results not shown). In order to verify that the presence of mannose 6-phosphate did not result from the conversion of mannose 1-phosphate by a mutase present in the membrane which was used as a source of EII ${ }^{\mathrm{Fru}}$, we added mannose 1-phosphate to a reaction medium that contained no PEP and tested for the presence of mannose 6phosphate using the assay described above. No mannose 6-phosphate could be detected after an incubation of $1 \mathrm{~h}$ at $37^{\circ} \mathrm{C}$, indicating that the mannose 6-phosphate detected in the PTS assay did not originate from the conversion of mannose 1-phosphate.

\section{DISCUSSION}

The protein $11 \mathrm{I}_{\mathrm{L}}^{\text {Man }}$ is essential for the activity of the mannose-PTS in S. salivarius (Bourassa et al., 1990; Gauthier et al., 1990). However, several $11 \mathrm{~L}_{\mathrm{L}}^{\mathrm{Man}}$-deficient mutants retain the ability to grow on $0.2 \%$ mannose, albeit at a reduced rate (Gauthier et al., 1990), and constitutively express an inducible EII ${ }^{\mathrm{Fru}}$ (Bourassa \& Vadeboncoeur, 1992). Results presented in this work indicated that this EII ${ }^{\text {Fru }}$ constituted a new route for the entry of mannose into $S$. salivarius. Mannose and fructose were recognized by the same transporters with different affinities. The constitutive mannose-PTS had a high affinity for mannose $(10 \mu \mathrm{M})$ and a lower affinity for fructose (approximately $65 \mu \mathrm{M}$ ) whereas the inducible fructose-PTS had a high affinity for fructose $(10 \mu \mathrm{M})$ and a low affinity for mannose $(180-200 \mu \mathrm{M})$. An identical situation was recently reported in Escherichia coli, although the affinity constant of the fructose P'TS for mannose is much higher (approximately $8 \mathrm{mM}$ ) (Kornberg \& Lambourne, 1992).

The inducible fructose-PTS of $S$. salivarius phosphorylates fructose at the C-1 position (Bourassa \& Vadeboncoeur, 1992). Even though mannose is also a substrate of this 


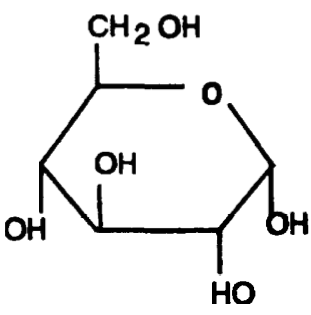

$\alpha-D-G l u c o s e$

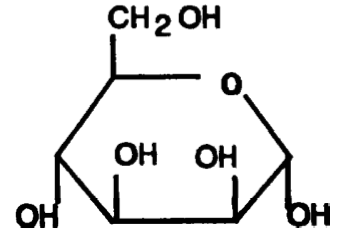

$\alpha-D-M a n n o s e$

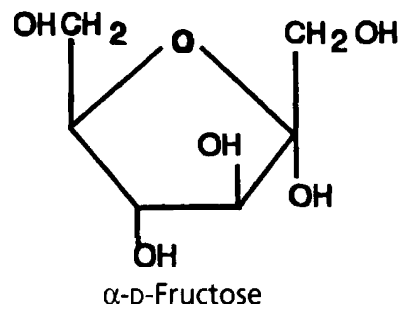

Fig. 4. Haworth projection formulae of $\alpha$-D-glucose, $\alpha-D-$ mannose and $\alpha$-D-fructose.

PTS, it is phosphorylated at the C-6 position. The same result was reported by Kornberg \& Lambourne (1992) for E. coli. Moreover, the fructose-PTS, contrary to the mannose-PTS, did not recognize glucose, which differs from mannose only by the position of the hydroxyl group on carbon 2. The Haworth projection formulae of these monosaccharides are shown in Fig. 4. As can be seen, the carbons that are phosphorylated by the PTS are those that are not involved in either the pyranose ring (carbon 6 in mannose) or in the furanose ring (carbons 1 and 6 in fructose). Therefore, one might speculate that mannose is phosphorylated at the C-6 position by the fructose-PTS because only carbons which are not members of the pyranose or the furanose rings could be phosphorylated by the P'TS. Moreover, as the fructose-PTS recognized fructose and mannose, but not glucose, it appears that common structural determinants must be found on fructose and mannose but not on glucose. As seen in Fig. 4 , the position of the hydroxyl group at the C-2 position in mannose, but not in glucose, mimics the $\mathrm{C}-3$ position configuration of fructose. We therefore suggest that this region of the molecule accounts for the specificity of the inducible EII ${ }^{\mathrm{Fru}}$. The orientation of the hydroxyl group at the $\mathrm{C}-2$ position in mannose and at the $\mathrm{C}-3$ position in fructose appear, however, to be different relative to the phosphorylated carbon (C-6 for mannose and C-1 for fructose). This difference obviously affects the affinity of the enzyme for the substrate as demonstrated in this work but is not as critical as the orientation of the hydroxyl group of carbon 2 for mannose and carbon 3 for fructose relative to the plane of the sugar (above or below the heterocycle) for the recognition of the sugar by the enzrime.

On the other hand, as EII ${ }^{\text {Man }}$ recognizes mannose, fructose and glucose, it appears that the C-2/C-3 region of these hexoses is not critical for their interaction with the mannose permease. However, the fact that EII ${ }^{\text {Man }}$ does not recognize galactose (Vadeboncoeur \& Trahan, 1982) suggests that the position of the hydroxyl group at the $C$ 4 position of the hexose (below the heterocycle in glucose, mannose and fructose but above the cycle in galactose) is important in determining the specificity of the mannose permease.

\section{ACKNOWLEDGEMENTS}

This research was supported by Medical Research Council of Canada operating grant MT-6979 to Christian Vadeboncoeur. Gilles Pelletier was supported by studentships from the Medical Research Council of Canada and from the Fonds pour la Formation de Chercheurs et l'Aide à la Recherche from the Province of Québec. Michel Frenette is a scholar of the Fonds de la Recherche en Santé du Québec. We thank Michel Pelletier for his help in the $\left[{ }^{32} \mathrm{P}\right] \mathrm{PEP}$ experiments and Gene Bourgeau for editorial assistance.

\section{REFERENCES}

Bourassa, S. \& Vadeboncoeur, C. (1992). Expression of an inducible enzyme II fructose and activation of a cryptic enzyme II glucose in glucose-grown cells of spontaneous mutants of Streptococcus salivarius lacking the low-molecular-mass form of III ${ }^{\text {Man }}$, a component of the phosphoenolpyruvate:mannose phosphotransferase system. J Gen Microbiol 138, 769-777.

Bourassa, S., Gauthier, L., Giguère, R. \& Vadeboncoeur, C. (1990). A III ${ }^{\text {Man }}$ protein is involved in the transport of glucose, mannose and fructose by oral streptococci. Oral Microbiol Immunol 5, 288-297.

Brochu, D., Trahan, L., Jacques, M., Lavoie, M. C., Frenette, M. \& Vadeboncoeur, C. (1993). Alterations in the cellular envelope of spontancous $11 \mathrm{I}_{\mathbf{L}}^{\text {Man }}$-defective mutants of Streptococcus salivarius. $J$ Gen Microbiol 139, 1291-1300.

Dixon, M. (1953). The determination of enzyme inhibition constants. Biocbem J 55, 170-177.

Gauthier, L., Bourassa, S., Brochu, D. \& Vadeboncoeur, C. (1990). Control of sugar utilization in oral streptococci. Properties of phenotypically distinct 2 -deoxyglucose-resistant mutants of Streptococcus salivarius. Oral Microbiol Immunol 5, 352-359.

Gracy, R. W. \& Noltman, E. A. (1968). Studies on phosphomannose isomerase. Isolation, homogeneity measurements, and determination of some physical properties. J Biol Chem 243, 3161-3168.

Hamilton, I. R., Gauthier, L., Desjardins, B. \& Vadeboncoeur, C. (1989). Concentration-dependent repression of the soluble and membrane components of the Streptococcus mutans phosphoenolpyruvate:sugar phosphotransferase system by glucose. $J$ Bacteriol 171, 2942-2948.

Kornberg, H. S. \& Lambourne, L. T. M. (1992). Role of the phosphoenolpyruvate-dependent fructose phosphotransferase system in the utilisation of mannose by Escherichia coli. Proc $\mathrm{R}$ soc Lond Ser B 250, 51-55.

Laemmli, U. K. (1970). Cleavage of structural proteins during the assembly of the head of bacteriophage T4. Nature 227, 680-685.

Lapointe, R., Frenette, M. \& Vadeboncoeur, C. (1993). Altered

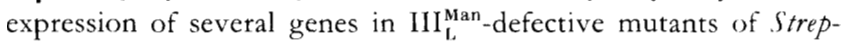
tococcus salivarius demonstrated by two-dimensional gel electrophoresis of cytoplasmic proteins. Res Microbiol 144, 305-316.

Mattoo, R. S. \& Waygood, E. B. (1983). An enzymatic method for $\left[{ }^{32} \mathrm{PEP}\right]$ phosphoenolpyruvate synthesis. Anal Biochem 128, 245-249.

Meadow, N. D., Fox, D. K. \& Roseman, S. (1990). The bacterial 
phosphoenolpyruvate: glycose phosphotransferase system. Annu Rev Biocbem 59, 497-542.

Postma, P. W., Lengeler, J. W. \& Jacobson, G. R. (1993). Phosphoenolpyruvate: carbohydrate phosphotransferase systems of bacteria. Microbiol Rev 57, 543-594.

Rodrigue, L., Lacoste, L., Trahan, L. \& Vadeboncoeur, C. (1988). Effect of nutritional constraints on the biosynthesis of the components of the phosphoenolpyruvate:sugar phosphotransferase system in a fresh isolate of Streptococcus mutans. Infect Immun 56, 518-522.

Thompson, J. (1987). Sugar transport in the lactic acid bacteria. In Sugar Transport and Metabolism in Gram-positive Bacteria, pp. 13-38. Edited by J. Reizer \& A. Peterkofsky. Chichester: Ellis Horwood.

Towbin, H., Staehelin, T. \& Gordon, J. (1979). Electrophoretic transfer of proteins from polyacrylamide gels to nitrocelluluse sheets: procedure and some applications. Proc Natl Acad Sci US A 76, 4350-4354.

Vadeboncoeur, C. (1984). Structure and properties of the phos- phoenolpyruvate:glucose phosphotransferase system of oral streptococci. Can J Microbiol 30, 495-502.

Vadeboncoeur, C. \& Gauthier, L. (1987). The phosphoenolpyruvate: sugar phosphotransferase system of Streptococcus salivarius. Identification of a III ${ }^{\text {Man }}$ protein. Can J Microbiol 33, 118-122.

Vadeboncoeur, C. \& Trahan, L. (1982). Glucose transport in Streptococcus salivarius. Evidence for the presence of a distinct phosphoenolpyruvate:glucose phosphotransferase system which catalyses the phosphorylation of $\alpha$-methyl glucoside. Can J Microbiol 28, 190-199.

Waygood, E. B., Mattoo, R. L., Erickson, E. \& Vadeboncoeur, C. (1986). Phosphoproteins and the phosphoenolpyruvate:sugar phosphotransferase system of Streptococcus salivarius. Detection of two different ATP-dependent phosphorylations of the phosphocarrier protein HPr. Can J Microbiol 32, 310-318.

Received 7 February 1994; revised 24 March 1994; accepted 18 April 1994. 